\title{
CARTOGRAFANDO O CIBERESPAÇO ${ }^{1}$
}

JoÃo SARMENTO ${ }^{2}$

O livro da autoria de MARTin Dodge (investigador no CASA - Centre for Advanced Spatial Analysis, da University College of London) е de Rов Кітснім (Professor de Geografia na Universidade Nacional da Irlanda em Maynooth) constitui uma importante contribuição para a análise espacial das novas tecnologias e da World Wide Web em particular. Este é sem dúvida um dos primeiros livros a explorar as geografias da Internet, resultado de uma ideia inicial de produzir um coffee-table book, que foi publicado também em 2001 pelos mesmos autores com o título de Atlas of Cyberspace. Apesar de incluir 100 mapas de grande qualidade - 28 deles a cor - este livro não pretende ser um Atlas do ciberespaço ${ }^{3}$, mas sim um texto académico sobre os impactes das tecnologias de informação e comunicação nas relações espaço-tempo e nas esferas culturais, sociais e económicas. Cartografar é no entanto importante pois (...) revela detalhes das estruturas de poder (...) do ciberespaço em termos de quem controla os sistemas, quem tem acesso a eles, de como os sistemas podem ser monitorizados, e de onde e como está o ciberespaço a ser usado (p. 81).

O livro está dividido em onze capítulos, que no nosso entender constituem duas partes distintas. A primeira parte é composta pelos três primeiros capítulos. Esta começa com uma introdução ao livro - Introducing cyberspace - que fornece algumas definições usadas posteriormente, e revela a história do ciberespaço. Este capítulo é substancialmente baseado num outro livro de Kiтchin, que três anos mais cedo abordou as Geografias do Ciberespaço ${ }^{4}$, sendo que a sua maior contribuição é a de organizar ideias e 'histórias' do ciberespaço e da evolução das tecnologias de informação que podemos encontrar noutras obras. Os dois capítulos seguintes - Geographies of the information society e Geographies of cyberspace, pretendem ilustrar argumentos que justifiquem, de um ponto de vista académico, a definição de ciberespaço como um espaço conceptual no contexto

1 Dodge M.; Kitchin R. (2001) - Mapping Cyberspace. Routledge, Nova Iorque. 260 p. (ISBN 0-415-19883-6).

2 Investigador no Núcleo de Investigação em Geografia e Planeamento da Universidade do Minho. Professor Auxiliar no Departamento de Geografia, Instituto de Ciências Sociais, Universidade do Minho, Campus de Azurém, Guimarães, Portugal. Tel.: +351 253510 561; Fax: +351 253510569. E-mail: j.sarmento@geografia.uminho.pt

3 Muitas das ilustrações do livro foram produzidas originalmente para web sites (nomeadamente o site produzido por um dos autores - www.cybergeography.com). A alteração de escala necessária para reduzir a informação que aparece num monitor de computador para uma página de texto resulta por vezes numa fraca legibilidade dos detalhes.

4 Kitchin, R. (1998)-Cyberspace. The World in the Wires. John Wiley \& Sons, Chichester. 
das tecnologias de informação e comunicação. Estes são porventura os capítulos menos bem conseguidos do livro, pois não fornecem dados novos resultantes de fontes primárias, ou experiências em primeira-mão, recorrendo sistematicamente a extensas análises de textos de outros autores, ficando-se no entanto bastante aquém da qualidade e brilho das obras de CASTELLS, por exemplo ${ }^{5}$. O capítulo três deveria ser incorporado no primeiro capítulo, pois não é mais do que uma segunda introdução aos temas do livro, sendo que a conclusão deste mesmo capítulo é claramente insuficiente, e em pouco contribui para a cadência da obra.

A segunda parte do livro engloba os capítulos quatro a onze, e discute diversas formas e exemplos das geografias do ciberespaço. É nestas páginas que encontramos a grande mais valia desta obra e a capacidade de síntese e clareza de escrita dos autores. Os capítulos quatro, cinco e seis - Introducing the cartographies of cyberspace, Mapping information and communication technologies e Spatialising cyberspace - respectivamente, analisam a qualidade e disponibilidade de dados para produzir cartografia, exemplificando este debate com mapas das redes digitais de comunicação, por exemplo, infra-estruturas como cabos, ligações entre anfitriões, endereços, domínios e fluxos de tráfego.

O capítulo sete - Mapping asynchronous media - analisa formas de cartografar meios de comunicação assíncrona, como sejam as mensagens de correio electrónico ou as listas de mensagens electrónicas, sendo que o capítulo oito - Mapping synchronous social spaces - debruça-se na cartografia das sociabilidades criadas em salas de conversa - chat rooms - ou MUD (Multi User Domains). Os capítulos finais da cartografia do ciberespaço consideram questões relacionadas com a cognição espacial nos ambientes virtuais e no mundo imaginário da ficção científica, e exploram os futuros imaginários das cartografias do ciberespaço.

Por ser um trabalho pioneiro, este livro fornece e abre muitas perspectivas sobre questões complexas como o design gráfico usado na tradução dos dados que possuímos sobre o ciberespaço para a sua cartografia. Ao mesmo tempo, apesar da complexidade e do carácter técnico de muitas destas questões, o leitor não tem necessariamente que possuir conhecimentos profundos sobre as tecnologias de informação e comunicação para poder apreciar e compreender este livro. Em conclusão, o livro é um claro contributo inovador para o debate sobre os espaços virtuais e para as formas como os geógrafos podem analisar estes territórios, procurando contextualizar as discussões no âmbito dos campos teóricos das ciências sociais. No último parágrafo do livro os autores respondem de forma clara às questões que foram colocando ao longo da obra, e nomeadamente na introdução, o espaço e a geografia continuam a ser importantes e em alguns casos adquiriram uma importância acrescida. (...) O ciberespaço é intrinsecamente espacial (p. 219).

5 Castells, M. (1996) - The Rise of the Network Society. Blackwell, Oxford. 